\title{
The anomalous high temperatures of November 2010 over Greece: meteorological and climatological aspects
}

\author{
K. Tolika, I. Pytharoulis, and P. Maheras \\ Department of Meteorology and Climatology, School of Geology, Aristotle University of Thessaloniki, Greece
}

Received: 23 February 2011 - Accepted: 22 July 2011 - Published: 10 October 2011

\begin{abstract}
This paper presents an analysis of the exceptionally high maximum $\left(T_{\max }\right)$ and minimum $\left(T_{\min }\right)$ temperatures which occurred during November 2010 and affected the entire Greek region. This severe "warm cold-season spell" was unusual because of its prolonged duration and intensity for the entire month and particularly the maximum temperature anomalies, which in comparison with the 1958-2000 climatological average, exceeded $5^{\circ} \mathrm{C}$ at several stations. Comparing the observed record with future projections from three regional climate models revealed that $T_{\max }$ and $T_{\min }$, on several days in November 2010, exceeded the 90th percentile of the simulated data. An examination of the atmospheric - synoptic conditions during this period showed that the anomalous high temperatures could probably be related to the negative phase of the Eastern Mediterranean Pattern (EMP), with an intense pole of negative anomalies located over the British Isles, and to the east, a second pole of positive anomalies, centred over the Caspian Sea. Finally, an attempt is made to further investigate the mechanisms responsible for this phenomenon, for example, the thermal forcing in the tropics (Niño 3 or Niño 3.4).
\end{abstract}

\section{Introduction}

During the past decade, many parts of the European region have experienced severe heat waves which resulted in serious consequences for society, the environment, the economy, tourism and agriculture. During the summer of 2003, "record breaking" high temperatures were observed in several Central European countries (Schär et al., 2003; Beniston, 2004; Beniston and Diaz, 2004). During 2007, the eastern Mediterranean and especially the Balkan Peninsula and Greece experienced a remarkably warm year (Busuioc et al., 2007;

Correspondence to: $\mathrm{K}$. Tolika

(diatol@geo.auth.gr)

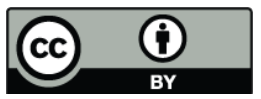

Founda and Giannakopoulos, 2009; Tolika et al., 2009). In all cases, the summer maximum and minimum temperatures were found to be the highest observed since the late 1940s (Beniston 2004; Tolika et al., 2009). When compared with future projections from regional climate models (RCMs), it is expected that these temperature conditions could potentially occur more than $50 \%$ of the time during the last decades of the 21st century (Beniston, 2007; Tolika et al., 2009).

It is not only the summer months that are characterised by extreme high temperatures. In one of his recent studies, Beniston (2005) indicated that the departures of maximum temperatures from their means (temperature anomalies) were larger during winter than in the summer at several high elevation regions in the Alps during the last decade of the 20th century. This supports the findings of our study over Greece (Tolika et al., 2009), where abnormally high temperatures were also observed during the cold season of 2007 , and it was concluded that winter minimum temperatures were statistically more extreme than the summer maxima.

During November 2010, Greece experienced a new "heat wave" event or, as termed by Beniston (2005), a new intense "warm cold-period spell". Anomalous high maximum and minimum temperatures were observed across the entire country and remained at high levels during the whole month with values which far exceeded the long term mean. Compared to the average temperatures of 1958-2000, it was found that the positive anomalies reached a value of $5^{\circ} \mathrm{C}$ at some stations. Also, according to the WMO, 2010 was the warmest of the last $150 \mathrm{yr}$ (Blanchet, 2011). Consequently, these abnormal and persistent warm conditions motivated our study which aimed to: (a) conduct a statistical analysis of the anomalous high temperatures during November 2010 across Greece - an investigation of their characteristics and a comparison with simulated RCM data as well as, (b) the examination of the meteorological - synoptic large scale atmospheric conditions that have possibly resulted in this warming.

(diatol@gen

Published by Copernicus Publications on behalf of the European Geosciences Union. 


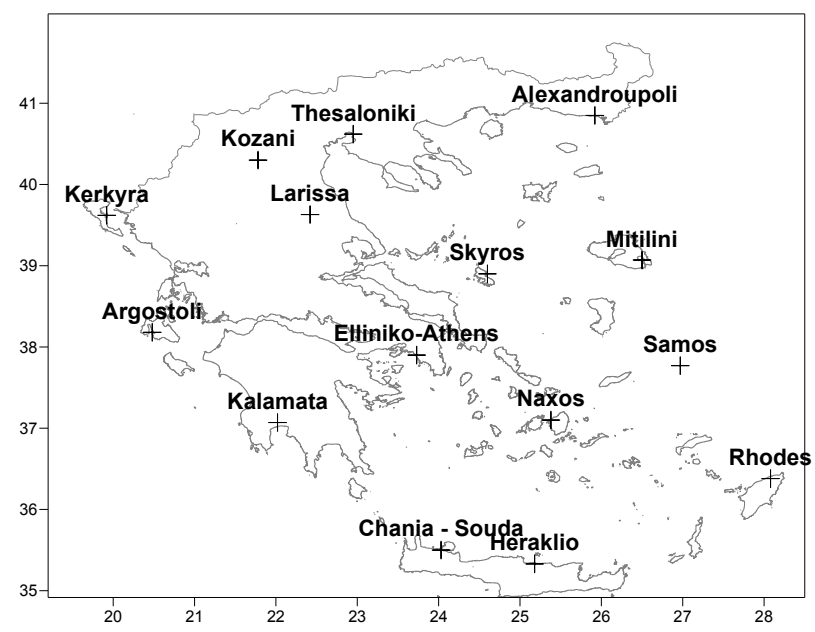

Fig. 1. Geographical distribution of the 15 stations under study.

\section{Data and methodology}

Daily maximum and minimum temperature data $\left(T_{\max }\right.$ and $T_{\min }$ hereafter) for November 2010 from 15 stations across the Greek region (Fig. 1) were used in the study. With the exception of Thessaloniki (data were recorded at the meteorological station located at the University of Thessaloniki; AUTh), daily $T_{\max }$ and $T_{\min }$ screen-level temperatures were provided by the National Climatic Data Center (NCDC) of NOAA (http://www.ncdc.noaa.gov). These values are postprocessing products of NCDC and are based on the reported SYNOP messages (of 06:00 and 18:00 UTC) and hourly or half-hourly METARs. Also, daily $T_{\max }$ and $T_{\min }$ data for the long term period 1958-2000, provided by the Hellenic National Meteorological Service, were utilised for the selected stations.

Regional climate $T_{\max }$ and $T_{\min }$ projections from three RCMs developed during the ENSEMBLES European project were utilised. Their spatial scale is $25 \mathrm{~km}$ and their projections were forced by the A1B SRES scenario, which is characterised as a pessimistic scenario as the $\mathrm{CO}_{2}$ concentration will increase up to $815 \mathrm{ppm}$ by the end of the century, and on a global scale temperatures will rise from between $2.5^{\circ} \mathrm{C}$ to $4.5^{\circ} \mathrm{C}$ (Nakicenovic et al., 2000). The simulations are driven by the same realisation of the ECHAM5 global circulation model. Daily data were available for the entire time period starting from 1951 up to 2100 . Table 1 shows baseline information for the RCMs and their simulations that were used in the study as well as their main references. For the present analysis 15 grid points were selected, the ones nearest (on land) to the stations under study. Using these simulated daily data for November maximum and minimum temperatures, several quantiles were computed for the last $30 \mathrm{yr}$ of the 21st century and compared with the corresponding observations of November 2010
In addition, the NCEP/NCAR reanalyses 1 (Kalnay et al., 1996) were retrieved from NOAA (http://www.esrl.noaa. gov/psd/data/gridded/data.ncep.reanalysis.html) in order to calculate the mean monthly climatological fields for the period 1958-2000. The data used in this analysis were air temperature, geopotential height and zonal/meridional wind components at the isobaric levels of $1000,850,500,300 \mathrm{hPa}$ on a regular $2.5^{\circ} \times 2.5^{\circ}$ global grid $\left(90^{\circ} \mathrm{N}-90^{\circ} \mathrm{S}, 0^{\circ} \mathrm{E}-\right.$ $\left.357.5^{\circ} \mathrm{E}\right)$ at the main synoptic hours (00:00, 06:00, 12:00 and 18:00 UTC). NCEP/NCAR reanalysis 1 sea surface temperatures (SSTs) for 2010 were also used and are provided on a Gaussian grid with $192 \times 94$ points $\left(88.542^{\circ} \mathrm{N}-88.542^{\circ} \mathrm{S}\right.$, $\left.0^{\circ} \mathrm{E}-358.125^{\circ} \mathrm{E}\right)$ at four times daily.

The NCEP/GFS (Yang et al., 2006) operational analyses of November 2010 were downloaded from the operational data server at NCEP (ftp://ftpprd.ncep.noaa.gov) and the NOMADS archive data server at NOAA (http://nomads. ncdc.noaa.gov) in order to calculate the mean monthly upper air fields for this period. The air temperature, geopotential height and zonal/meridional wind components were retrieved at the above mentioned pressure levels. They were available on a $0.5^{\circ} \times 0.5^{\circ}$ regular global grid, four times daily, at the main synoptic hours. The necessary variables were interpolated to the $2.5^{\circ} \times 2.5^{\circ}$ grid of NCEP reanalysis grid in order to enable the production of the upper air anomaly fields.

\section{Results}

\subsection{Temperature analysis}

The comparison of the mean November $2010 T_{\max }$ to the equivalent long term mean $T_{\max }$ of 1958-2000 showed that, for all the stations under study, the mean November 2010 $T_{\max }$ is much higher than for the long term mean. Their differences (TmaxNov2010-TmaxNov1958-2000) vary from between $1.6^{\circ} \mathrm{C}$ (Kalamata) to $5.4^{\circ} \mathrm{C}$ (Thessaloniki) and are generally higher over the northern stations. The absolute $T_{\max }$ recorded during November 2010 were also high ranging from $22^{\circ} \mathrm{C}$ at Kozani up to $29.4{ }^{\circ} \mathrm{C}$ at Chania, and in this case the absolute $T_{\max }$ values were higher at stations in the southern parts of the country (Table 2). However, it should be emphasised that the main characteristic of the November $2010 T_{\max }$ is not the extremely high values (neither for mean $T_{\max }$ - with the exception of the stations of Alexandroupoli, Kozani, Mitilini, Samos and Thessaloniki nor for the absolute $T_{\max }$ ), but is the persistence and duration of these temperatures. According to Fig. 2, illustrating the daily Nov2010 $T_{\max }$ along with the mean daily $T_{\max }$ for the period 1958-2000, it is clear that the warming phenomenon started almost at the beginning of November and lasted until the end of the month. More specifically, the high $T_{\max }$ values persisted until the 2 nd or, at some stations, the 3 December. From the 4 December a cold invasion of air over the country resulted in a drop in temperature of $6^{\circ} \mathrm{C}$ to $10^{\circ} \mathrm{C}$ in one 
Table 1. The Regional Climate Models used in the study (Acronyms, Institute of origin, Spatial resolution, Emission scenarios, Main references).

\begin{tabular}{llllll}
\hline Model Acronym & Institute & Driving GCM & Scenario & Resolution & Main References \\
\hline HIRHAM & $\begin{array}{l}\text { DMI (Danish Meteorological Institute, } \\
\text { Denmark) }\end{array}$ & ECHAM5-r3 & A1B & 25 km & Haugen and Haakenstad (2006) \\
RACMO2 & $\begin{array}{l}\text { KNMI (Royal Netherlands Meteorol- } \\
\text { ogical Institute, the Netherlands) }\end{array}$ & ECHAM5-r3 & A1B & 25 km & Lenderink et al. (2003) \\
REMO & $\begin{array}{l}\text { MPI (Max-Planck-Institute for } \\
\text { Meteorology, Germany) }\end{array}$ & ECHAM5-r3 & A1B & 25 km & Jacob (2001) \\
& & & & & \\
\hline
\end{tabular}
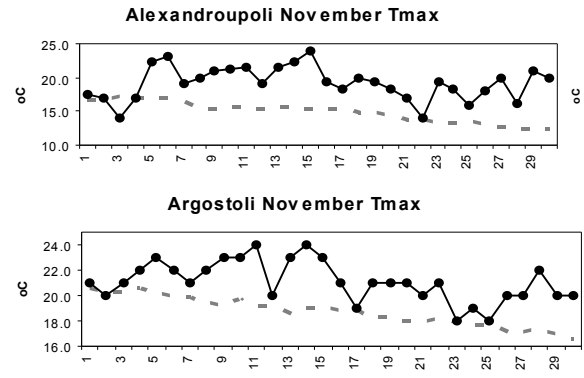

Chania - Souda November Tmax

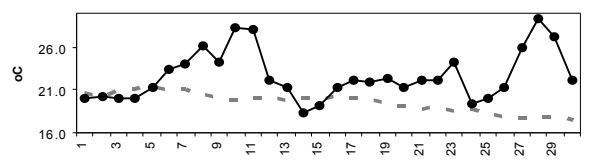

Elliniko- Athens November Tmax

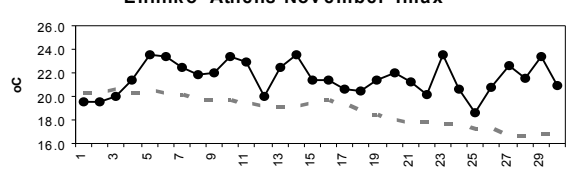

Heraklio November Tmax

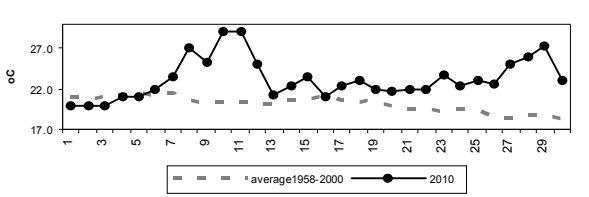

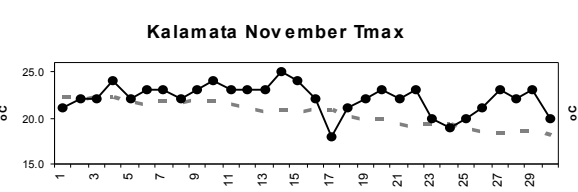

Kerkyra November Tmax

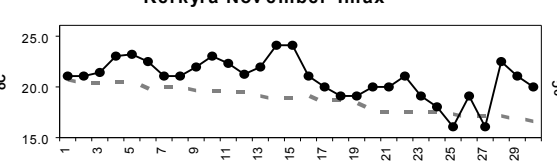

Kozani November Tmax
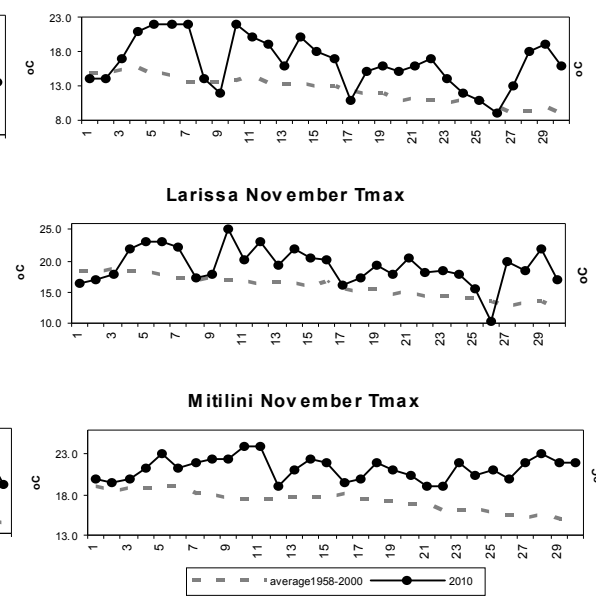

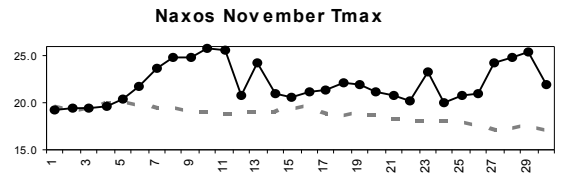

Rhodes November Tmax

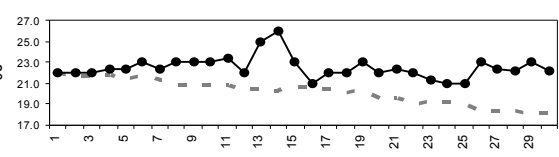

Samos November Tmax

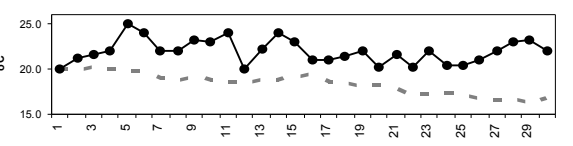

Skyros November Tmax
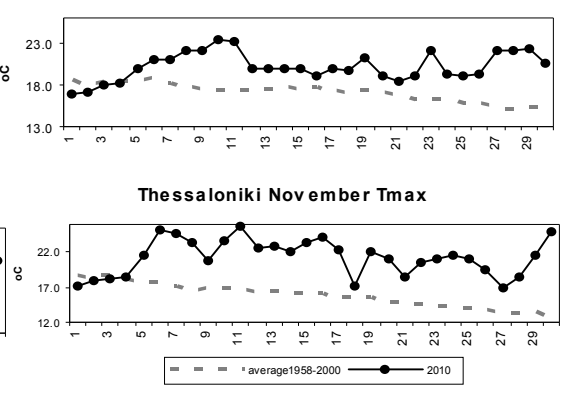

Fig. 2. Daily maximum temperature time-series for the 15 stations under study, for November 2010 and for the mean November long term period 1958-2000.

day. Although, for some stations, the Nov2010 $T_{\max }$ may, for one or two days, have been lower than the long term mean, the general characteristic was one of warming over the study area. The highest $T_{\max }$ of the month appeared roughly during the end of the first ten-day period and during the last week of November 2010.

The results concerning $T_{\min }$ are quite similar, apart from the starting date of the warming. It was found that high minimum temperatures did not appear from the beginning of the month (except for Argostoli and Kozani) but with a delay (compared to $T_{\max }$ ) from 2 days (in Kozani) up to 7 days (in Alexandroupoli and Skyros) (not shown). Moreover, as it can be seen from Table 2, in some northern continental stations (Kozani and Thessaloniki) the mean $T_{\min }$ of November 2010 were higher than those recorded for 19582000. Finally, it should be mentioned that the $T_{\min }$ anomalies (TminNov2010-TminNov1958-2000) were much lower than those for $T_{\max }$ ranging from $1.2^{\circ} \mathrm{C}$ (Kalamata) to $4.1^{\circ} \mathrm{C}$ (Argostoli). 
Table 2. Maximum and minimum November temperature mean values, for the year of 2010 and for the long term period 1958-2000 for the 15 stations under study.

\begin{tabular}{|c|c|c|c|c|c|c|}
\hline \multirow[b]{2}{*}{ Stations } & \multicolumn{2}{|c|}{$\begin{array}{c}\text { November } \\
T_{\max } \text { Average }\end{array}$} & \multirow{2}{*}{$\begin{array}{c}\text { Maximum Nov. } \\
T_{\max } \text { Average } \\
1958-2000\end{array}$} & \multicolumn{2}{|c|}{$\begin{array}{c}\text { November } \\
T_{\text {min Average }}\end{array}$} & \multirow{2}{*}{$\begin{array}{c}\text { Maximum Nov } \\
T_{\min } \text { Average } \\
1958-2000\end{array}$} \\
\hline & 2010 & 1958-2000 & & 2010 & 1958-2000 & \\
\hline Alexandroupoli & 19.2 & 14.9 & 18.4 & 10.3 & 6.6 & 11.3 \\
\hline Argostoli & 21.1 & 18.7 & 21.0 & 16.8 & 12.7 & 15.0 \\
\hline Chania-Souda & 22.7 & 19.6 & 23.3 & 14.4 & 13.0 & 15.4 \\
\hline Elliniko-Athens & 21.6 & 18.8 & 21.9 & 14.5 & 12.1 & 14.7 \\
\hline Heraklio & 23.2 & 20.1 & 23.5 & 15.1 & 13.5 & 15.6 \\
\hline Kalamata & 22.1 & 20.5 & 24.0 & 11.1 & 9.8 & 12.4 \\
\hline Kerkyra & 20.8 & 18.7 & 21.0 & 13.0 & 10.0 & 13.3 \\
\hline Kozani & 16.4 & 12.4 & 16.6 & 7.8 & 3.9 & 7.1 \\
\hline Larissa & 19.2 & 15.9 & 19.3 & 7.6 & 5.8 & 9.2 \\
\hline Mitilini & 21.2 & 17.3 & 20.6 & 15.1 & 11.4 & 15.0 \\
\hline Naxos & 22.1 & 18.7 & 22.1 & 16.4 & 13.6 & 15.6 \\
\hline Rhodes & 22.5 & 20.2 & 23.7 & 16.8 & 14.5 & 16.6 \\
\hline Samos & 22.0 & 18.4 & 21.2 & 15.8 & 12.2 & 16.5 \\
\hline Skyros & 20.2 & 17.1 & 20.3 & 14.0 & 12.0 & 15.1 \\
\hline Thessaloniki & 21.3 & 15.9 & 19.6 & 11.6 & 8.0 & 11.2 \\
\hline
\end{tabular}

\subsection{Comparison with RCM future projections}

In order to conduct as thorough an analysis as possible of the intensity of this phenomenon of high temperatures during November 2010, we utilised the daily November $T_{\max }$ and $T_{\min }$ data from three RCMs (RACMO2-KNMI, REMOMPI and HIRHAM-DMI, the closest grid points to the stations under study) for the computation of several percentiles ( $Q 10, Q 25, Q 50, Q 75$ and $Q 90$ ) for the last $30 \mathrm{yr}$ of the $21 \mathrm{st}$ century (2071-2100). The results were compared to the daily observational time series both for November 2010 as well as the daily long term means for the period 1958-2000. Due to space limitations, the results for six selected stations from RACMO2-KNMI only are presented here (Fig. 3). It was found that in the case of RACMO2-KNMI, for all the stations, several days of November 2010 presented both $T_{\max }$ and $T_{\min }$ values that exceeded the $Q 90$ percentile of the simulated data. The highest excesses were found for Thessaloniki and Heraklio $\left(T_{\max }\right.$ and $\left.T_{\min }\right)$ and for Mitilini $\left(T_{\min }\right)$. In general, for almost all of the stations used in the study, the majority of days in November 2010 showed maximum and minimum temperatures greater than the $50 \%$ quantile. The comparison with the other two RCMs (REMO-MPI and HIRHAM-DMI) further supported the unusual characteristics of the November 2010 warming but the results were not as marked as in the RACMO2-KNMI simulation. The number of days with temperatures exceeding the $90 \%$ quantile is less and for some stations, none of the days reach this quantile limit. Especially in the case of Larissa, a highly continental station, the November $2010 T_{\min }$ values are below the $Q 75$ and some are even lower than the $Q 25$, for both the RCM projections. This may be attributed to the fact that these RCMs (REMO-MPI and HIRHAM-DMI) show particularly high minimum temperatures for the grid point closer to Larissa, possibly due to an overestimation of the influence of the sea and vegetation cover (not shown).

\subsection{Meteorological aspects - links with the atmospheric circulation}

The analysis of the synoptic conditions at several geopotential height levels $(1000 \mathrm{hPa}, 850 \mathrm{hPa}, 500 \mathrm{hPa}$ and $300 \mathrm{hPa})$ during November 2010, as well as the equivalent anomaly fields (differences from the mean monthly field of the study period 1958-2000), showed that the meteorological cause of the prevalence of high $T_{\max }$ and $T_{\min }$ during the whole month is evident in all geopotential height fields. However, it is more intense at the upper levels.

More specifically, at the $1000 \mathrm{hPa}$ level, it was found that a low geopotential height field covers Northern Europe, centred over the British Isles (Fig. 4a). This field extends up to the western Mediterranean and forms a trough which is orientated from Algeria to Scandinavia. In contrast, higher geopotential heights, centred over the Caspian Sea, dominate the eastern Mediterranean and extend even further to the east. A northwestern flow, originated from the Atlantic, occurs over the western Mediterranean while to the east the prevailing flow is southwestern from the Sahara. The anomalies composite map shows that the entire European region, as well as the Mediterranean, is covered with negative geopotential height anomalies that decline eastwards (Fig. 4b).

Analogous were the results from the mean geopotential height field and the anomalies field at $850 \mathrm{hPa}$ for November 2010. The main difference in comparison to the 

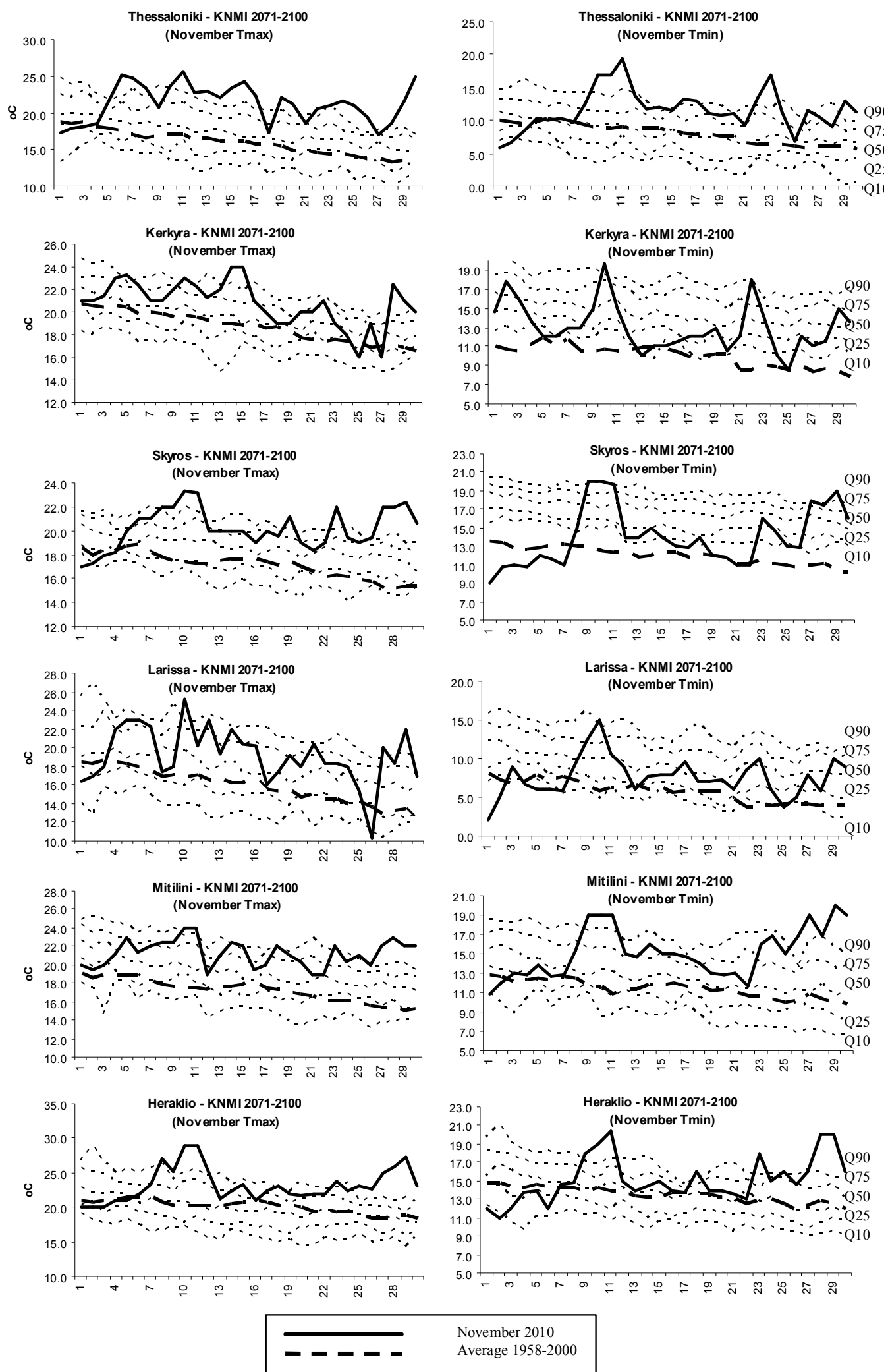

Fig. 3. Daily $T_{\max }$ and $T_{\min }$ values during November 2010 (solid lines) and November mean $T_{\max }$ and $T_{\min }$ values for the long term period 1958-2000 (dashed lines). Daily November $T_{\max }$ and $T_{\min }$ quantiles $(Q 10, Q 25, Q 50, Q 75$ and $Q 90)$ for the future period 2071-2100 as derived according to the A1B emission scenario from the RACMO2 - KNMI model, for six selected stations. 
a) Geop. Height (gpm) $1000 \mathrm{hPa}$ Nov 2010

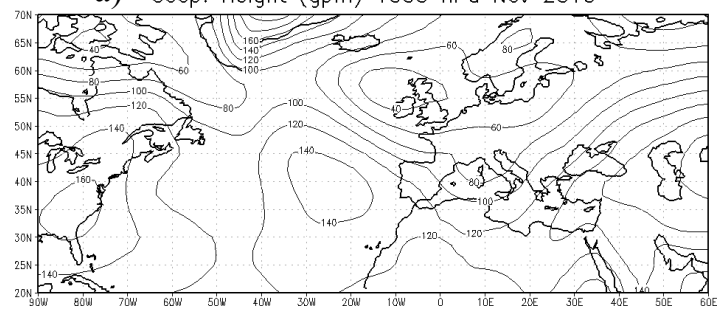

c) Geop. Height (gpm) $500 \mathrm{hPa}$ Nov 2010

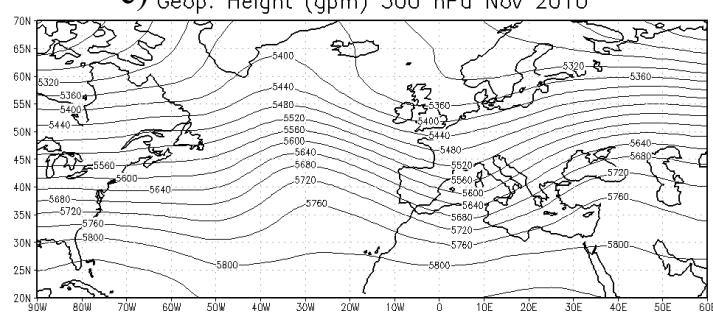

b) Geop. Height Anom. (gpm) $1000 \mathrm{hPa}$ Nov 2010

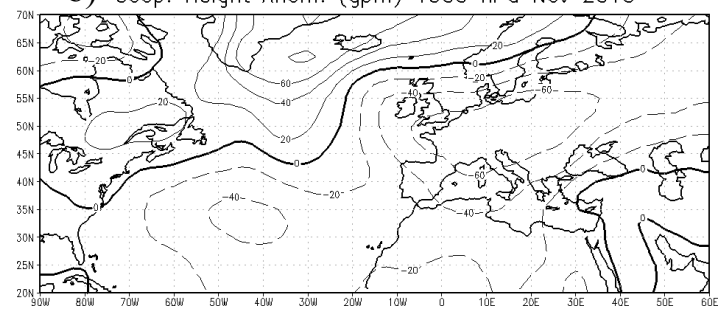

d) Geop. Height Anom. (gpm) $500 \mathrm{hPa}$ Nov 2010

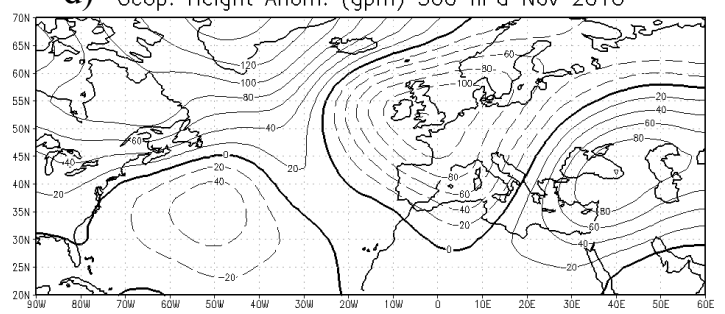

Fig. 4. Mean geopotential fields for November 2010, and mean anomaly field (with respect to the long term 1958-2000 November mean field) at $1000 \mathrm{hPa}$ and $500 \mathrm{hPa}$.

equivalent $1000 \mathrm{hPa}$ maps is a zone of positive anomalies found over the east of eastern Mediterranean (not shown).

The analysis of geopotential heights at the $500 \mathrm{hPa}$ level supports the synoptic conditions found in the previous two fields. A trough, from Sahara to Scandinavia, results in an intense northwestern flow from the Atlantic Ocean to the western Mediterranean and a southwestern flow to the east (Fig. 4c). The corresponding anomaly field is even more revealing of the prevailing conditions. An intense pole of negative anomalies is located over the British Isles covering Western, Central and Northern Europe as well as western parts of the Mediterranean. To the east, a second pole of positive anomalies, centred between the Black Sea and the Caspian Sea, characterise the eastern parts of the domain (Fig. 4d).

Finally, with respect to the geopotential height fields (mean and anomalies) at the $300 \mathrm{hPa}$ level, the atmospheric circulation presents many similarities to those already described. The trough axis has the same location and intensity as in the previous fields. The two poles in the anomaly field are found at the same locations, with the negative one located over the British Isles and the positive one to the east of the Black Sea. However, the two anomalies poles are more intense than in the $500 \mathrm{hPa}$ anomaly field, almost by $60 \mathrm{gpm}$. Moreover, the positive anomaly field extends further to the west and covers southern Italy and parts of the Adriatic Sea (not shown).

Furthermore, based on the fact that sometimes monthly average maps tend to smooth the meteorological fields, the mean geopotential heights (at $1000 \mathrm{hPa}$ and $500 \mathrm{hPa}$ ) and the associated anomaly maps for two specific days (relative to the long term 1958-2000 mean of the corresponding days) were also incorporated in order to get an insight of the extreme conditions during this event. The selected days were the 10 and 11 November 2010. During these two dates the average $T_{\max }$ and $T_{\min }$ (from all the stations under study) exhibited their maximum values. Moreover, most of the stations (separately) presented the highest maximum and minimum temperatures.

Figure 5 shows that a dipole with low geopotential heights over northern Europe and high geopotential heights over the eastern Mediterranean prevailed at $1000 \mathrm{hPa}$ on 10 and 11 November 2010. At $500 \mathrm{hPa}$, a transitional trough was affecting Western and Central Europe, while a ridge was located over eastern Mediterranean. At $1000 \mathrm{hPa}$, the negative height anomalies reached -200 gpm over Central Europe on 10 November and -320 gpm over the eastern Atlantic on 11 November. These anomalies were larger than in the mean monthly charts (Fig. 4) and were associated with a wide low-pressure area of multiple centers and a deepening cyclone, respectively. Over the eastern Mediterranean, the daily anomalies were either close to or slightly more positive than the mean monthly values of November 2010 at $1000 \mathrm{hPa}$. At $500 \mathrm{hPa}$ the daily anomalies exceeded -240 to $-280 \mathrm{gpm}$ over Western Europe, 120 to $160 \mathrm{gpm}$ over the eastern Mediterranean and $200 \mathrm{gpm}$ further east (beyond the Caspian) on the two selected days. The fact that during these two days the anomalies exhibited similar patterns but stronger values than in the mean monthly charts, is indicative of stronger southwesterly flow over eastern Mediterranean, bringing warm air masses from the Sahara.

The position and intensity of the anomaly field at all geopotential height levels, and mainly at $500 \mathrm{hPa}$ and $300 \mathrm{hPa}$, resemble the negative phase of the Eastern Mediterranean Pattern (EMP) as determined by Hatzaki et al. (2007, 2009). This teleconnection pattern identified at $500 \mathrm{hPa}$ and $300 \mathrm{hPa}$ from October to April weakens at $700 \mathrm{hPa}$ while it 
a) Geop. Height (gpm) $1000 \mathrm{hPa} 10$ Nov 2010

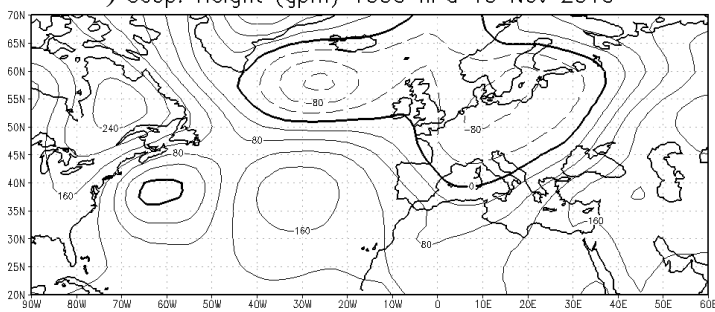

c) Geop. Height (gpm) $500 \mathrm{hPa} 10$ Nov 2010

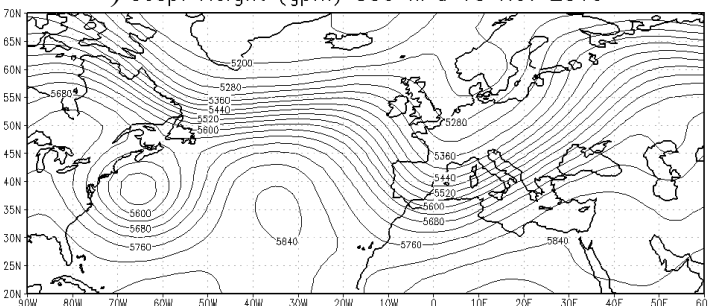

e) Geop. Height (gpm) $1000 \mathrm{hPa} 11$ Nov 2010

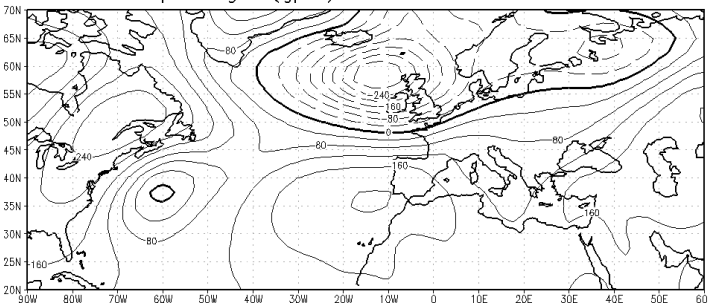

g) Geop. Height (gpm) $500 \mathrm{hPa} 11$ Nov 2010

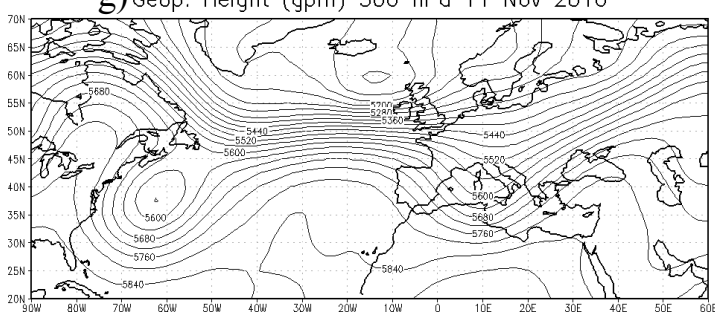

b) Geop. Height Anom. (gpm) $1000 \mathrm{hPa} 10$ Nov 2010

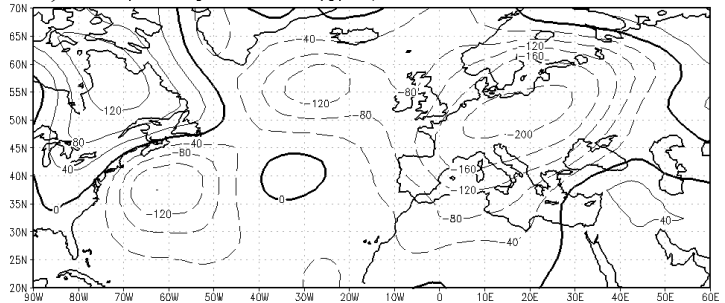

d) Geop. Height Anom. (gpm) $500 \mathrm{hPa} 10$ Nov 2010

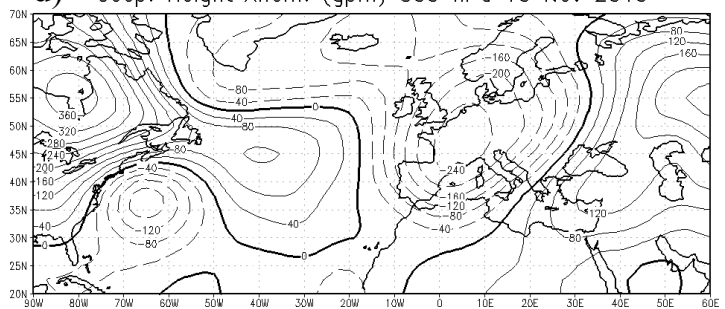

f) Geop. Height Anom. (gpm) $1000 \mathrm{hPa} 11$ Nov 2010

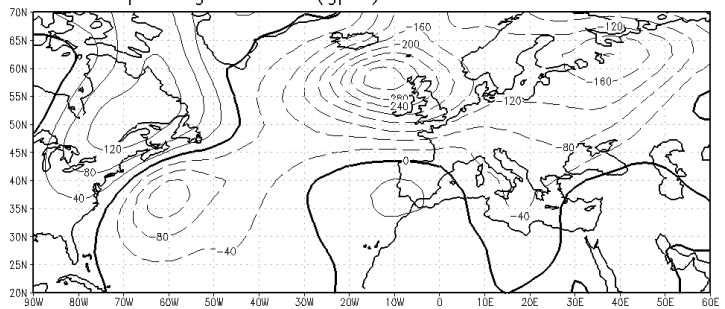

h) Geop. Height Anom. (gpm) $500 \mathrm{hPa} 11$ Nov 2010

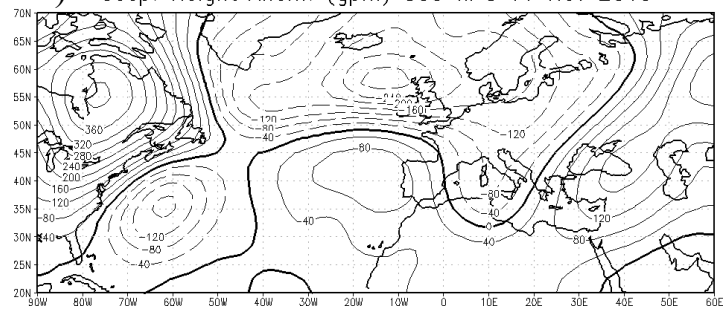

Fig. 5. Mean geopotential fields on 10 and 11 November 2010, and mean anomaly field (with respect to the long term 1958-2000 mean field of the corresponding day) at $1000 \mathrm{hPa}$ and $500 \mathrm{hPa}$.

does not exist clearly at lower levels (Hatzaki et al., 2007). According to the authors, the EMP exhibits a pronounced inter-monthly variation in its location, structure and strength. During the winter months, the EMP is defined as follows: $\mathrm{EMP}=\operatorname{gpm}\left(25^{\circ} \mathrm{W}, 52.5^{\circ} \mathrm{N}\right)-\mathrm{gpm}\left(22.5^{\circ} \mathrm{E}, 32.5^{\circ} \mathrm{N}\right)$, but during autumn the northern pole is shifted eastwards over the British Isles or Central Europe. In our case, the southern anomaly pole identified for November 2010 is located further to the north and east $\left(40^{\circ} \mathrm{E}, 40^{\circ} \mathrm{N}\right)$ than the one of the EMP. However, the identification of the synoptic conditions of November 2010 as the negative phase of the EMP is reinforced by the fact that the polar front jet has a zonal structure while the northern pole of the EMP forms at the east side of the jet. On the other hand, the subtropical jet does not seem to play any role in the development of this phenomenon, a finding which is in agreement with the conclusions of Hatzaki et al. (2007).

Thus, the main factor of the predominance of high temperatures (both maximum and minimum) across Greece during November 2010, seems to be related to the occurrence of intense southwestern atmospheric circulation over the Greek region and eastwards, mainly at mid - upper tropospheric levels, as a result of the negative phase of the EMP. From the analysis of daily atmospheric circulation patterns it was found that these synoptic conditions persisted during the entire month as well as the first three days of December 2010 (not shown). Finally, apart from the anomalous high temperatures, the rainfall conditions over the country during 
November 2010 (above average in northern Ionian Sea and Epirus and below average in the rest of Greece), are in agreement with the findings of Hatzaki et al. (2007).

\subsection{Meteorological aspects - the role of the tropical- equatorial heating}

It is well known that thermal forcing in the tropics could initiate Rossby wave propagation from there to the mid latitudes resulting in large scale zonal asymmetries of the western atmospheric circulation (Fraedrich and Müller, 1992; Hoerling et al., 1997; Flocas and Hatzaki, 2009; Bulic, 2010). For the investigation of the existence of such a cause, which could lead to the negative EMP phase as derived from the analysis of the aforementioned phenomenon, sea surface temperature (SST) anomaly maps were constructed on a monthly basis for the whole of 2010. Due to space limitations, only the November SST anomaly pattern is presented here (Fig. 6a), but the average SST anomalies for the two selected areas in the tropical Pacific (Niño 3 or Niño 3.4, Trenberth, 1997) and SE Pacific are illustrated on a monthly basis for 2010 in Fig. 6b. The SST anomaly patterns from January to May 2010 showed a positive anomaly zone that diminishes gradually with time. More specifically, it is observed systematically over the tropical areas of the Pacific Ocean, along the Equator, roughly from $180^{\circ} \mathrm{W}$ to $90^{\circ} \mathrm{W}$. In contrast, over the southern Pacific, along the west coast of South America, there is a negative anomaly zone which also diminishes gradually to May 2010. During the same time period, another negative anomaly zone is detected over the northern Atlantic Ocean, orientated from the southwest (Gulf of Mexico) to the northeast (Western Europe) (not shown). From June 2010, a narrow negative anomaly zone starts to form around the Equator (from $150^{\circ} \mathrm{W}$ to $90^{\circ} \mathrm{W}$ ) and the negative anomaly SST zone over the Atlantic is reinforced strongly. In July, the two Equator negative anomaly zones (Niño 3 or Niño 3.4) become more intense, while both the intensity and extent of the equivalent zone over the North Atlantic is reduced. During August, the Pacific negative anomaly zone becomes even stronger and its eastern side extends to the south along South America up to $25^{\circ} \mathrm{S}$. In contrast, the negative anomalies over the Atlantic Ocean are almost eliminated and replaced by a positive anomaly field. This pattern remains almost the same in September, whereas in October the negative anomaly Equator zones are even more reinforced.

Furthermore, in November 2010 (Fig. 6), when the anomalous high temperatures were detected over Greece, the Equator negative anomaly zones (Niño 3 or Niño 3.4) slightly attenuate in comparison to October (not shown), whereas the positive anomaly pattern over the Atlantic is found to be more intense. Finally, for December (high temperatures remained until the 3rd), a strong change in the SST anomaly pattern was observed. The negative anomaly zones along the Equator (Niño 3 and Niño 3.4) present an even greater intensity, especially at its eastern side, and extend over South

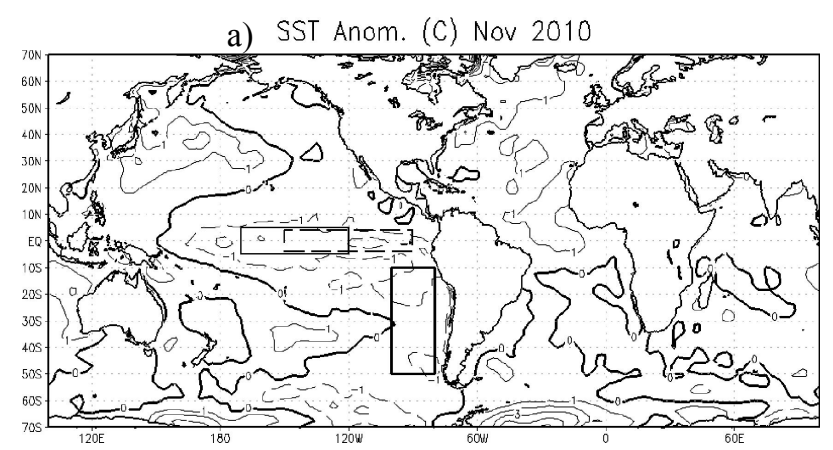

b)

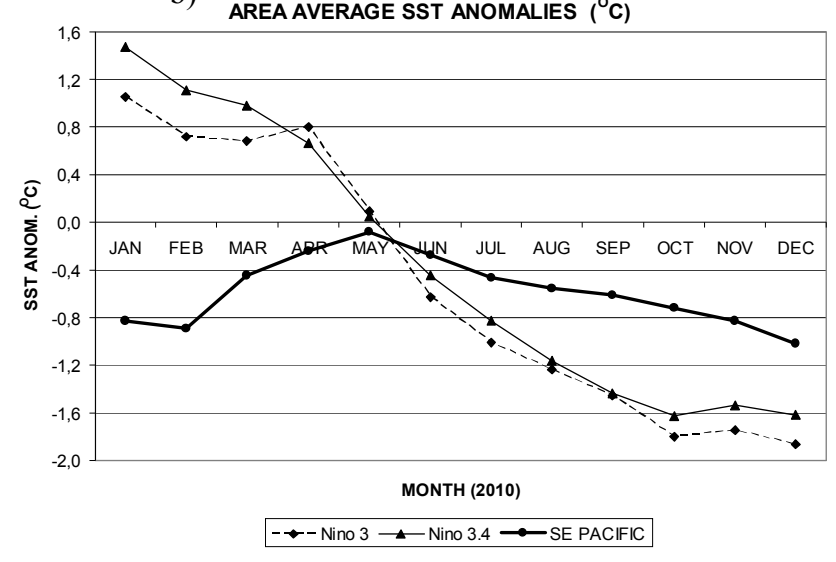

Fig. 6. (a) Monthly mean SST anomalies $\left({ }^{\circ} \mathrm{C}\right)$ of November 2010 relative to the long-term mean of November 1958-2000 (negative values are indicated by dashed contours) and (b) timeseries of area averaged monthly mean SST anomalies in 2010 for the three boxes depicted in (a). Niño 3 (long dashed frame): $4^{\circ} \mathrm{S}-4^{\circ} \mathrm{N}, 150^{\circ} \mathrm{W}-$ $90^{\circ} \mathrm{W}$, Niño 3.4 (solid frame): $5^{\circ} \mathrm{S}-5^{\circ} \mathrm{N}, 170^{\circ} \mathrm{W}-120^{\circ} \mathrm{W}$, SE Pacific (bold solid frame): $50^{\circ} \mathrm{S}-10^{\circ} \mathrm{S}, 100^{\circ} \mathrm{W}-80^{\circ} \mathrm{W}$.

America up to $60^{\circ} \mathrm{S}$. Conversely, the positive anomalies over the North Atlantic are attenuated and limited over the northern and southern parts of the North Atlantic. Another weak negative anomaly field can be detected over the Gulf of Mexico which extends eastwards, and a second one is found along the coasts of Western Europe (not shown).

\section{Conclusions and Discussion}

During November 2010, Greece experienced abnormally warm conditions with remarkably high maximum and minimum temperatures observed across the country. Both $T_{\max }$ and $T_{\min }$ were characterised by large departures from the long term mean, reaching up to $5.4^{\circ} \mathrm{C}$. The observations derived from 15 stations suggest that this warming phenomenon was unusual in its persistence during the entire month. In contrast, this month was characterised as the coldest November across the United Kingdom since 1993 and the snowiest since that of November 1965.

Further research conducted using simulated data from three RCMs reinforced our conclusion of the unusual 
severity of the November warming phenomenon. The comparison of observed $T_{\max }$ and $T_{\min }$ with future projections revealed that these temperatures are likely to occur, in some cases, more than $90 \%$ of the time during the last three decades of the 21 st century. These findings are even higher than those identified in our previous analysis on the summer heat wave in Greece during 2007 (Tolika et al., 2009).

The synoptic setting for this event is defined at different geopotential height levels $(1000 \mathrm{hPa}, 850 \mathrm{hPa}, 500 \mathrm{hPa}$ and $300 \mathrm{hPa}$ ) by the presence of two poles in the anomaly fields. The negative pole is observed over the British Isles and the positive one to the east of the Black Sea. This anomaly pattern, which is more intense in the upper tropospheric levels $(500 \mathrm{hPa}$ and $300 \mathrm{hPa})$, could be associated with the negative phase of the Eastern Mediterranean Pattern (EMP) defined by Hatzaki et al. (2007, 2009). Moreover, the 500hPa anomaly pattern revealed a very negative anomaly over the North Sea and a very positive one over the Caspian. This coincides with the negative phase of the North Sea - Caspian Pattern (NCP) (Kutiel et al., 2002). The authors highlight in their research that during this negative NCP phase, positive temperature departures were observed during November (and also during other months) all over the eastern Mediterranean as well as Greece (Kutiel et al., 2002).

The investigation of other meteorological aspects showed that a possible trigger mechanism for the anomalous warm November in Greece could be thermal forcing in the tropics. The analysis of global SST anomalies indicated a narrow negative anomaly zone which started to form around the Equator and a second one along the South American coast which gradually became more intense from June until November 2010. Moreover, over the North Atlantic, a positive SST anomaly field is found from August until November 2010, when it presented its highest intensity.

The Greek region seemed to have experienced the mildest form of this warming phenomenon while the centre of intense high temperatures was located over the Caspian and Black Sea. The temperature anomalies at $1000 \mathrm{hPa}$ reached $7^{\circ} \mathrm{C}$ there, and at $850 \mathrm{hPa}$ even $9^{\circ} \mathrm{C}$. In contrast, in Scandinavia and generally in Northern Europe the temperature anomalies were negative, almost $-4{ }^{\circ} \mathrm{C}$.

One of the main questions raised in this study is the possibility that these high temperatures during November 2010 in the Greek region and to the east, could be related with the positive and negative SST anomalies in the tropics and therefore with El Niño and La Niña events, especially given that during the second half of 2010, La Niña was at its strongest in the last $100 \mathrm{yr}$ (Blanchet, 2011). Previous studies have demonstrated that the influence of warm and cold SST anomalies over the Equator (Niño 3 or Niño 3.4) present a substantial shift in the location and the intensity of the anomalies over the Pacific - North American (PNA) and the North Atlantic European (NAE) regions (Hoerling et al., 1997; DeWeaver and Nigam, 2002; Bulic, 2010). It was found that there is a kind of symmetry between the spatial pattern in the Northern Hemisphere of the atmospheric response to the warm and cold phase. Yet the influence is more intense for warm events (Bulic, 2010). Moreover, Bulic (2010) underlines that "the atmospheric signal for the NAE region does not indicate such clear dependence on the Niño 3.4 index".

The results of other studies concerning the influence of the tropical heating for the development of positive and negative anomalies in the upper atmosphere over the NAE region are quite contradictive. According to Flocas and Hatzaki (2009), the positive phase of this heating is responsible for the development of the northern pole of the positive phase of the EMP while the negative phase of the tropical heating does not seem to play an important role in the development of the EMP. In contrast, consistent with the findings of Bulic (2010), the positive phase of Niño 3.4 is associated with a negative anomaly centre at the $200 \mathrm{hPa}$ level, close to the British Isles, which is equivalent to the negative pole of the EMP and the negative phase of Niño 3.4 is related to a centre of positive anomalies over the North Atlantic. In addition, according to some of the results of DeWeaver and Nigam (2002), the winters of 1992 and 1999, with warm and cold anomalies in the region of Niño 3.4, presented respective positive and negative geopotential height anomalies at the $200 \mathrm{hPa}$ level in the NAE region, equivalent to the north pole of the EMP. This is in agreement with the results of the present study.

In other words, negative SST anomalies in the tropics (Niño 3 or Niño 3.4) stimulate a "wave train" which moves gradually eastwards and could generate the atmospheric circulation over the North Atlantic in the region of the north pole of the EMP. However, from the previous analysis, it becomes evident that several other geographical or dynamical factors could also play an important role and result in a different circulation pattern in the domain of interest. According to Hoerling et al. (1997), “... the phase difference between warm and cold event wave trains is largest in late fall...".

Therefore, in conclusion, it is evident that the main cause of the abnormal high temperatures during November 2010 in Greece and to the east of the country is the intense southwestern circulation over the region, mainly in the upper atmosphere, due to the negative phase of the EMP during the whole month. Regarding the role of the heating or cooling of the tropics for the development of the EMP, two of the main mechanisms that are probably involved are outlined below:

1. An intense cooling in the tropics (Niño 3 or Niño 3.4) during the period of September-November 2010 resulted in the stimulation of a wave train that moved progressively to the east and along with the heating of the NAE region, formed equivalent atmospheric conditions to the negative EMP phase.

2. The established atmospheric conditions over the Atlantic which correspond to the negative phase of the EMP could be the result of the influence of the positive 
and negative anomalies observed in the tropics during the whole of 2010, which were combined with other, up to now unknown, geographical or dynamical factors. These latter sources may be the link connecting the tropical Pacific forcing with a possible distant European Mediterranean response (Fraedrich, 1994).

Thus, even though in our analysis a physical basis for the linearity between the climate signals in extratropical regions and extremes in tropical SST was found, several other factors support the nonlinearity between the two phenomena. Since the question remains open, the authors intend to analyse further the causes of this extreme event and aim to utilise different approaches in the investigation of the various aspects that could be related to these remarkably high temperatures over Greece.

Acknowledgements. This study has been supported by the European Commission ENSEMBLES project (Contract number GOCE-CT-2003-505539) and the GABARDINE project (518118). NCEP Reanalysis data provided by the NOAA/OAR/ESRL PSD, Boulder, Colorado, USA, from their Web site at http://www.esrl.noaa.gov/psd/.

Edited by: N. R. Dalezios

Reviewed by: H. Kutiel and another anonymous referee

\section{References}

Beniston, M.: The 2003 heat wave in Europe: A shape of things to come?, An analysis based on Swiss climatological data and model simulations, Geophys. Res. Lett., 31, L02202, doi:10.1029/2003GL018857, 2004.

Beniston, M.: Warm winter spells in the Swiss Alps: strong heat waves in a cold season?, A study focusing on climate observations at the Saentis high mountain site, Geophys. Res. Lett., 32, L01812, doi:10.1029/2004GL021478, 2005.

Beniston, M.: Entering into the "greenhouse century": Recent record temperatures in Switzerland are comparable to the upper temperature quantiles in a greenhouse climate, Geophys. Res. Lett., 34, L16710, doi:10.1029/2007GL030144, 2007.

Beniston, M. and Diaz, H. F.: The 2003 heat wave as an example of summers in a greenhouse climate? Observations and climate model simulations for Basel, Switzerland, Glob. Planet. Change, 44, 73-81, 2004.

Blanchet, G.: SMF info, La lettre d'information de la Société Météorologique de France, SMF 22, 1-7, Janvier, 2011.

Bulic, H. I.: The sensitivity of climate response to the wintertime Niño 3.4 sea surface temperature anomalies of 1855-2002, International J. Climatol., doi:10.1002/joc.2255, 2010.

Busuioc, A., Dumitrescu, A., Soare, E., and Orzan, A.: Summer anomalies in 2007 in the context of extremely hot and dry summers in Romania, Romanina, J. Meteorol., 9, 1-17, 2007.

DeWeaver, E. and Nigam, S.: Linearity in ENSO's Atmopsheric Response, J. Climate, 15, 2446-2461, 2002.

Flocas, H. and Hatzaki, M.: Climatic variability in Eastern Mediterranean: Dynamic mechanisms and impact on regional climate, Energy, Environment, Ecosystems, Development and Land- scape Architecture, ISSN: 1790-5095, ISBN: 978-960-474-125$0,2009$.

Founda, D. and Giannakopoulos, C.: The exceptionally hot summer of 2007 in Athens, Greece, Glob. Planet Change, 67(3-4), 227236, 2009.

Fraedrich, K.: An ENSO impact on Europe? A review, Tellus, 46A, 541-552, 1994.

Fraedrich, K. and Müller, K.: Climate Anomalies in Europe associated with ENSO extremes, Int. J. Climatol., 12, 25-31, 1992.

Hatzaki, M., Flocas, H. A., Asimakopoulos, D. N., and Maheras, P.: The eastern Mediterranean teleconnection pattern: identification and definition, Int. J. Climatol., 27, 727-737, 2007.

Hatzaki, M., Flocas, H. A., Giannakopoulos, C., and Maheras, P.: The impact of eastern Mediterranean teleconnection pattern on the Mediterranean climate, J. Climate, 22(4), 977-992, 2009.

Haugen, J. E. and Haakenstad, H.: Validation of HIRHAM version 2 with $50 \mathrm{~km}$ and $25 \mathrm{~km}$ resolution, RegClim General Technical Report, No. 9. 159-173, 2006.

Hoerling, M. P., Kumar, A., and Zhong M.: El Niño, La Niña and the Nonlinearity of their Teleconnections, J. Climate, 10, 17691786, 1997.

Jacob, D.: A note of the simulation of the annual and inter-annual variability of the water budget over the Baltic Sea drainage basin, Meteorol. Atmos. Phys., 77, 61-73, 2001.

Kalnay, E., Kanamitsu, M., Kistler, R., Collins, W., Deaven, D., Gandin, L., Iredell, M., Saha, S., White, G., Woollen, J., Zhu, Y., Chelliah, M., Ebisuzaki, W., Higgins, W., Janowiak, J., Mo, K. C., Ropelewski, C., Wang J., Leetmaa, A., Reynolds, R., Jenne, R., and Joseph, D.: The NCEP/NCAR 40-year reanalysis project, Bull. Amer. Meteor. Soc., 77, 437-470, 1996.

Kutiel, H., Maheras, P., Türke, M., and Paz, S.: North Sea - Caspian Pattern (NCP) - an upper level atmospheric teleconnection affecting the eastern Mediterranean - implications on the regional climate, Theor. Appl. Climatol. 72, 173-192, 2002.

Lenderink. G., van den Hurk B., van Meijgaard E., van ulden A., and Cuijpers H.: Simulation of present - day climate in RACHMO2: first results and model developments. Technical Report TR-252, Royal Netherlands Meteorological Institute, De Bilt, 2003.

Nakicenovic, N., Alcamo, J., Davis, G., de Vries, B., Fenhann, J., Gaffin, S., Gregory, K., Grübler, A., Yong Jung, T., Kram, T., Rovere, E., Michaelis, L., Mori, S., Morita, T., Pepper, W., Pitcher, H., Price, L., Riahi, K., Roehrl, A., Rogner, H., Sankovski, A., Schlesinger, M., Shukla, P., Smith, S., Swart, R., van Rooijen, S., Victor, N., and Dadi, Z.: IPCC Special Report on Emissions Scenarios, Cambridge University Press, Cambridge, 2000.

Schär, C., Vidal, P. L., Lüthi, D., Frei, C., Häberli, C., Liniger, M.-A., and Appenzeller C.: The role of increasing temperature variability in European summer heatwaves, Nature, 427, 332336, 2003.

Tolika, K., Maheras, P. and Tegoulias, I.: Extreme temperatures in Greece during 2007: Could this be a "return to the future"? Geophys. Res. Lett., 36, L10813, doi:10.1029/2009GL038538, 2009.

Trenberth, K. E.: The definition of El Niño, Bull. Amer. Meteorol. Soc., 78(12), 2771-2777, 1997.

Yang, F., Pan, H.-L., Krueger, S. K., Moorthi, S., and Lord, S. J.: Evaluation of the NCEP Global Forecast System at the ARM SGP Site, Mon. Weather Rev., 134, 3668-3690, 2006. 